\title{
Theoretical Description for Anti-COVID-19 Drug Remdesivir Electrochemical Determination, Assisted by Squaraine Dye- $\mathrm{Ag}_{2} \mathrm{O}_{2}$ Composite
}

\author{
Volodymyr V. Tkach 1,2,*(D), Marta V. Kushnir ${ }^{1}$, Sílvio C. de Oliveira ${ }^{2}$, Yana G. Ivanushko ${ }^{3}$, Alla V. \\ Velyka $^{3}$, Anzhelika F. Molodianu ${ }^{3}$, Petro I. Yagodynets ${ }^{1}$, Zholt O. Kormosh 4,*iD, \\ Lucinda Vaz dos Reis ${ }^{5}$, Olga V. Luganska ${ }^{6}$, Karina V. Palamarek ${ }^{7}$, Yuliia L. Bredikhina ${ }^{8,9}$ \\ 1 Chernivtsi National University, 58000, Kotsyubyns 'ky Str. 2, Chernivtsi, Ukraine \\ 2 Universidade Federal de Mato Grosso do Sul, Av. Sen. Felinto. Müller, 1555, C/P. 549, 79074-460, Campo Grande, MS, \\ Brazil \\ Bukovinian State Medical University, 58001, Teatralna Sq., 9, Chernivtsi, Ukraine \\ Eastern European National University, 43000, Voli Ave., 13, Lutsk, Ukraine \\ Universidade de Trás-os-Montes e Alto Douro, Quinta de Prados, 5001-801, Folhadela, Vila Real, Portugal \\ Zaporizhzhia National University, 69600, Zhukovsky Str. 66, Zaporizhzhia, Ukraine \\ Chernivtsi Institute of Trade and Economics of KNTEU, 58000, Central Sq, 9, Chernivtsi, Ukraine \\ 8 Melitopol State Pedagogical University, 72300, Melitopol, Hetmanska Str., 20, Ukraine \\ 9 Khortytska Natsionalna Navchalno-Reabilitatsiyna Akademiya, 69000, Naukove Mistechko, 59, Khortytsia Island, \\ Zaporizhzhya, Ukraine \\ * Correspondence: nightwatcher2401@gmail.com (V.V.T.); zholt1971@ukr.net, kormosh@eenu.edu.ua (Z.O.K.);

Received: 1.08.2020; Revised: 29.08.2020; Accepted: 30.08.2020; Published: 2.09.2020

\begin{abstract}
For the first time, the remdesivir anti-COVID-19 drug electrochemical determination has been evaluated theoretically. In this work, an anodic process involving the Squaraine Dye $-\operatorname{Ag}_{2} \mathrm{O}_{2}$ composite has been evaluated. The mechanism of the electroanalytical process is branched, which implies relatively dynamic behavior. Nevertheless, the correspondent mathematical model analysis, made by linear stability theory and bifurcation analysis, confirms the composite electroanalytical efficiency as an electrode modifier.
\end{abstract}

Keywords: COVID-19; remdesivir; electrochemical sensor; squaraine dye; silver (I, III) oxide; electrochemical oscillations; stable steady-state.

(C) 2020 by the authors. This article is an open-access article distributed under the terms and conditions of the Creative
Commons Attribution (CC BY) license (https://creativecommons.org/licenses/by/4.0/).

\section{Introduction}

In 2019-2020 the world was influenced by a strange virus infection [ $1-4]$. The virus structure was resembling the known 2003 atypical pneumonia virus SARS, Middle East $\beta$ coronavirus MERS, and newly found bat coronavirus, which received the code name of SARSCoViD2. Yet the proper infection has been put the code name COVID-19. The pandemic outbreak has lead to the cancellation and postposition of different events, including the European Football Cup and Summer Olympics. [5 - 6]. The development of an effective drug and vaccine is still in progress.

The clinical trials have confirmed the efficiency of Remdesivir drug (Fig. 1) [7 - 10]. It manifested exclusive efficiency and activity against COVID-19 in patients with mild and moderate symptoms. It was the first EU-approved drug against COVID-19. 


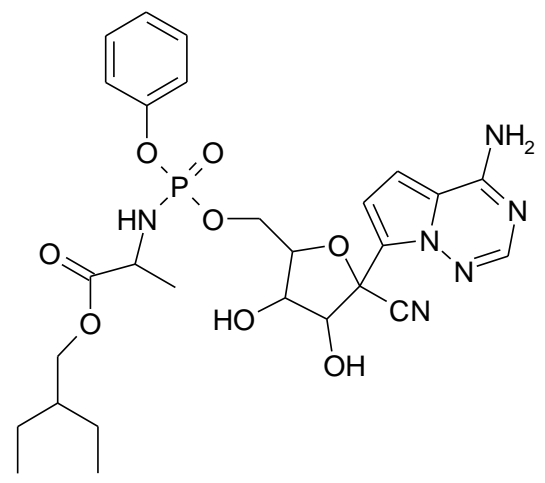

Figure 1. Remdesivir.

Nevertheless, remdesivir has shown some adverse effects [11-14], like respiratory insufficiency, reduction of erythrocyte and thrombocyte concentrations in blood, excess of melanin secretion, and allergic reactions. Moreover, as it contains a nitrile group, it may show high toxicity while in excess. Therefore, the development of efficient methods for remdesivir electrochemical determination is really actual [15 - 18], and the electroanalytical methods, yet used for similar drugs [19-21], could give it a good service.

Taking into account the remdesivir chemical composition, it is possible to conclude that this compound may be detected either anodically or cathodically. In the first case, strong oxidants should be used to oxidize the molecule, due to the presence of strong electron acceptors therein.

One of the oxidants, which may be used for this purpose, is silver (I, III) oxide (Fig. 2).

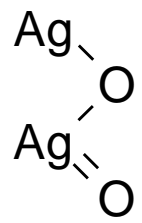

Figure 2. Silver (I, III) oxide structural formula.

It has already been used in gas masks during World War II to filter out the carbon (II) oxide by the reaction:

$$
\mathrm{Ag}_{2} \mathrm{O}_{2}+\mathrm{CO} \rightarrow \mathrm{Ag}_{2} \mathrm{CO}_{3}
$$

Nowadays, it is used in electrochemical cells as an oxidant [22]. Thus, its use in electroanalytical systems isn't discarded. Nevertheless, in order to stabilize it and make more efficient its sensing activity, it's strongly recommended to stabilize it by organic material, and the squaraine dye may easily be used for this purpose [23-26].

Nevertheless, the organic electrooxidation processes (including the electropolymerization) tend to be accompanied by electrochemical instabilities. These instabilities include the oscillatory changes in electrochemical potential and monotonic instabilities [27 - 29] and influence the sensing properties of the composite.

Thus, in order to investigate the parameter values, correspondent to the most efficient electroanalytical function of the system, like also verify the possibility and probability of the electrochemical instabilities in this system, an a priori theoretical observation of the electrochemical determination of remdesivir.

In this work, we analyze the remdesivir electrochemical determination, assisted by the composite of silver (I, III) oxide nanoparticles, stabilized by a squaraine dye. In order to achieve it, we realize the specific goals: the suggestion of the mechanism of the reaction consequence, 
leading to the appearance of an analytical signal; development of the balance equation mathematical model, correspondent to the electroanalytical system; analysis and interpretation of the model in terms of the electroanalytical use of the system; the seek for the possibility of electrochemical instabilities and for the factor, causing them; the comparison of the mentioned system's behavior with similar ones, hybrid organic-inorganic composites [30 - 35].

\section{Materials and Methods}

\subsection{System and its modeling.}

Remdesivir molecule contains four fragments, capable of oxidizing. Taking into account the facility of the electrooxidation of pentose fragment, it is oxidized firstly. The pyridinic nitrogen, passivated phenolic ring and pyrrolo[a,b](1,2,4-triazine) moiety are oxidized next. Two polymerization possibilities are foreseen.

Therefore, the remdesivir $\mathrm{Ag}_{2} \mathrm{O}_{2}$ - assisted electrochemical determination mechanism may be represented as in Fig. 3:

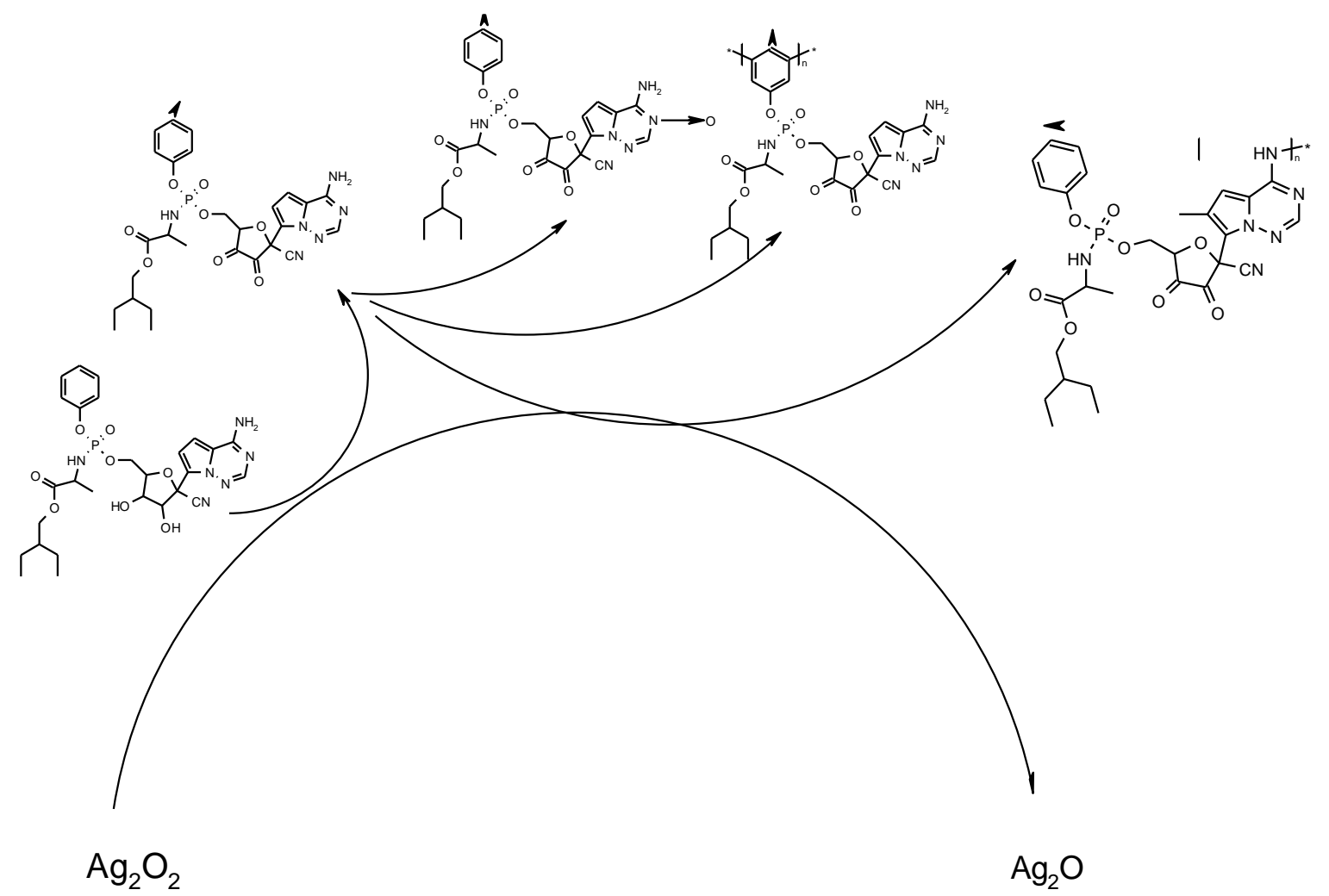

Figure 3. The scheme for Remdesivir electrochemical determination, assisted by Squaraine Dye $-\mathrm{Ag}_{2} \mathrm{O}_{2}$.

The role of the squaraine dye, used as the matrix to host the silver (I, III) oxide, is to both stabilize the inorganic phase and serve as an electron transfer mediator for the electroanalytical system.

Thus, in order to describe the system's behavior, we introduce three variables:

$\mathrm{c}$ - remdesivir concentration in the pre-surface layer; $\mathrm{co}$ - remdesivir partially oxidized form pre-surface concentration; s - silver (I) oxide surface coverage degree.

To simplify the modeling, we suppose that the reactor is intensively stirred, so we can neglect the convection flow. Also, we assume that the background electrolyte is in excess, so we can neglect the migration flow. The diffusion layer is supposed to be of a constant thickness, equal to $\delta$, and the concentration profile in it is supposed to be linear. 
It is possible to show that the electroanalytical process will be described by the threedimensional equation set, exposed as:

$$
\left\{\begin{array}{c}
\frac{d c}{d t}=\frac{2}{\delta}\left(\frac{\Delta}{\delta}\left(c_{0}-c\right)-r_{1}\right) \\
\frac{d c_{0}}{d t}=\frac{2}{\delta}\left(r_{1}-r_{21}-r_{22}-r_{23}\right) \\
\frac{d s}{d t}=\frac{1}{S}\left(r_{1}+r_{21}+r_{22}+r_{23}-r_{3}\right)
\end{array}\right.
$$

Herein, $\Delta$ is the diffusion coefficient, $\mathrm{c}_{0}$ is the remdesivir bulk concentration, $\mathrm{S}$ is the silver (I) oxide maximal surface concentration, and the parameters $r$ are the correspondent oxidant and polymerization reaction rates, expressed as:

$$
\begin{aligned}
& r_{1}=k_{1} c(1-s)^{2} \\
& r_{21}=k_{21} c_{0}(1-s) \\
& r_{22}=k_{22} c_{O}^{2 n-2}(1-s)^{n-1} \\
& r_{23}=k_{23} c_{O}^{2 m-2}(1-s)^{m-1} \\
& r_{3}=k_{3} s \exp \frac{2 F \varphi_{0}}{R T}
\end{aligned}
$$

in which the parameters $\mathrm{k}$ are the correspondent rate constants, $\mathrm{m}$ and $\mathrm{n}$ are monomer unit chain lengths in each of two polymerization scenarios, $\mathrm{F}$ is the Faraday number, $\mathrm{R}$ is the universal gas constant, and $\mathrm{T}$ is the absolute temperature.

In this system, the electrochemical determination of remdesivir is gradual due to the electrochemical oxidation of the pentose fragment, followed by N-oxidation and electropolymerization in two ways. Nevertheless, as all of the additional chemical stages do not influence the DEL capacitance and ionic force, the electroanalytical system will resemble the described in [30-35], as shown below.

\section{Results and Discussion}

In order to describe the behavior of the system with remdesivir electrochemical determination, assisted by a composite $\mathrm{Ag}_{2} \mathrm{O}_{2}$ - Squaraine dye, we analyze the equation set (2) by means of linear stability theory and bifurcation analysis. The steady-state Jacobian matrix members will be exposed as:

in which:

$$
\left(\begin{array}{lll}
a_{11} & a_{12} & a_{13} \\
a_{21} & a_{22} & a_{23} \\
a_{31} & a_{32} & a_{33}
\end{array}\right)
$$

$$
\begin{aligned}
& a_{11}=\frac{2}{\delta}\left(-\frac{\Delta}{\delta}-k_{1}(1-s)^{2}\right) \\
& a_{12}=0 \\
& a_{13}=\frac{2}{\delta}\left(2 k_{1}(1-s)\right) \\
& a_{21}=\frac{2}{\delta}\left(k_{1}(1-s)^{2}\right) \\
& a_{22}=\frac{2}{\delta}\left(-k_{21}(1-s)-(2 n-2) k_{22} c_{O}^{2 n-3}(1-s)^{n-1}-(2 m-2) k_{23} c_{O}^{2 m-2}(1-s)^{m-1}\right) \\
& \underline{a_{23}}=\frac{2}{0}\left(k_{21} c_{0}+(n-1)\left(k_{22} c_{0}^{2 n-2}(1-s)^{n-2}\right)+(m-1)\left(k_{22} c_{0}^{2 m-2}(1-s)^{m-2}\right)-\right. \\
& \left.2 k_{1}(1-s)\right) \\
& a_{31}=\frac{1}{S}\left(k_{1}(1-s)^{2}\right) \\
& a_{32}=\frac{1}{s}\left(k_{21}(1-s)+(2 n-2) k_{22} c_{O}^{2 n-3}(1-s)^{n-1}+(2 m-2) k_{23} c_{O}^{2 m-2}(1-s)^{m-1}\right)
\end{aligned}
$$




$$
\begin{aligned}
& a_{33}=\frac{1}{s}\left(-2 k_{1}(1-s)-k_{21}(1-s)-(2 n-2) k_{22} c_{O}^{2 n-3}(1-s)^{n-1}-(2 m-\right. \\
& \text { 2) } \left.k_{23} c_{O}^{2 m-2}(1-s)^{m-1}-k_{3} \exp \frac{2 F \varphi_{0}}{R T}+j k_{3} s \exp \frac{2 F \varphi_{0}}{R T}\right)(17)
\end{aligned}
$$

Contrarily to the similar systems [30 - 35], the oscillatory behavior in this system, despite remaining possible, is of less probability. It is explained by the absence of DEL influences of chemical stages present in similar systems. Thus, the unique main-diagonal element, which may be possible (and, consequently, responsible to the positive callback, causing the Hopf bifurcation), is $+j k_{3} s \exp \frac{2 F \varphi_{0}}{R T}>0$ if $\mathrm{j}>0$, describing the cyclic DEL capacitance changes during the electrochemical stage. This factor is common for the great majority of the electroanalytical systems and is realized in a sufficient manner to cause significant oscillations far beyond the detection limit. The oscillations are expected to be frequent and of small amplitude.

Yet if the mentioned element is negative, the steady-state stability is warranted. Really, applying the Routh-Hurwitz criterion to the Jacobian matrix and introducing new variables, having it rewritten as (18):

$$
\frac{4}{\delta^{2} S}\left|\begin{array}{ccc}
-\kappa-\Xi & 0 & \Lambda \\
\Xi & -\Sigma & P-\Lambda \\
\Xi & \Sigma & -P-\Lambda-\Omega
\end{array}\right|
$$

and opening the brackets and applying the condition Det $\mathrm{J}<0$, salient from the criterion, we obtain the steady-state stability requirement (19):

$$
-\kappa(2 \Sigma \Lambda+\Sigma \Omega)+2 \Lambda \Xi \Sigma<0
$$

As in [30-35], the system will be diffusion-controlled, defining the vast parameter region of the steady-state stability. From the electroanalytical point of view, it is correspondent to the linear dependence between the electrochemical parameter and the drug concentrations, describing an efficient electroanalytical process, even more stable than in similar systems [30-35].

Thus, it is possible to conclude that the $\mathrm{Ag}_{2} \mathrm{O}_{2}$ - squaraine dye composite is an efficient electrode modifier for the omeprazole electrochemical determination.

The monotonic instability, correspondent to the detection limit, from the electroanalytical point of view, is also probable if the destabilizing and stabilizing influences are equal. Its conditions will be described as:

$$
-\kappa(2 \Sigma \Lambda+\Sigma \Omega)+2 \Lambda \Xi \Sigma=0
$$

The same model may be used for the electrochemical determination of remdesivir, assisted by silver (I, III) oxide, stabilized by another conjugated material. Yet the use of cobalt (IV) oxide in some conditions excludes the N-oxide formation, annihilating the $\mathrm{r}_{21}$. In the rest, the model will be similar to described above. Also, if only one polymerization scenario is realized, the element $r_{22}$ or $r_{23}$ is annihilated, simplifying the system.

\section{Conclusions}

From the system with the electrochemical determination of remdesivir on $\mathrm{a}_{\mathrm{Ag}_{2} \mathrm{O}_{2}-}$ Squaraine dye composite, it was possible to conclude that: as in similar systems, the electroanalytical process is diffusion-controlled; the linear dependence between the electrochemical parameter and concentration of the drug is realized in a broad topological parameter region. The composite is an efficient electrode modifier for remdesivir electrochemical determination; the oscillatory behavior in this system is less probable than in 
the similar systems, being caused uniquely and exclusively by the DEL influences of the electrochemical stage.

\section{Funding}

This research received no external funding.

\section{Acknowledgments}

This research has no acknowledgment.

\section{Conflicts of Interest}

The authors declare no conflict of interest.

\section{References}

1. Chauhan, S. Comprehensive review of coronavirus disease 2019 (COVID-19). Biomed. J. 2020, https://doi.org/10.1016/j.bj.2020.05.023

2. Harapan, H.; Itoh, N.; Yufika, A.; Winardi, W.; Keam, S.; Te, H.; Megawati, D.; Hayati, Z.; Wagner, A.L.; Mudatsir, M. Coronavirus disease 2019 (COVID-19): A literature review. Journal of Infection and Public Health 2020, 13, 667-673, https://doi.org/10.1016/j.jiph.2020.03.019.

3. Tay, M.Z.; Poh, C.M.; Rénia, L.; MacAry, P.A.; Ng, L.F.P. The trinity of COVID-19: immunity, inflammation and intervention. Nature Reviews Immunology 2020, 20, 363-374, https://doi.org/10.1038/s41577-020-0311-8

4. Alsayed, R.; Kadhom, M.; Yousif, E.; Sabir, D.K., An Epidemiological Characteristic of the COVID-19 Among Children, Lett. Appl. NanoBioSci. 2020, 9, 1156-1164, https://doi.org/10.33263/LIANBS93.11561164

5. Figueroa-Valverde, L.; Díaz-Cedillo, F.; López-Ramos, M.; Rosas-Nexticapa, M.; Mateu-Armad, M.V.; Garcimarrero, R.A.; Cauich-Carrillo, R.; Ortiz-Ake, Y. Design and Synthesis of Five Cyclobuta-1,3-Dien1-yl-Steroid Derivatives to Evaluate Their Theoretical Activity Against COVID-19. Lett. Appl. NanoBioSci. 2020, 9, 1177-1187, https://doi.org/10.33263/LIANBS93.11771187

6. Hosny, N.M.; Sherif, Y. Molecular Docking Study on Some Isonicotinoyl Hidrazide Derivatives as Potencial Inhibitors of COVID-19. Lett. Appl. NanoBioSci. 2020, 9, 1217-1224, https://doi.org/10.33263/LIANBS93.12171224

7. Eastman, R.T.; Roth, J.S.; Brimacombe, K.R.; Simeonov, A.; Shen, M.; Patnaik, S.; Hall, M.D. Remdesivir. A Review of Its Discovery and Development Leading to Emergency Use Authorization for Treatment of COVID-19. ACS Cent. Sci. 2020, 6, 672-683, https://doi.org/10.1021/acscentsci.0c00489.

8. Grein, J.; Ohmagari, N.; Shin, D.; Diaz, G.; Asperges, E.; Castagna, A.; Feldt, T.; Green, G.; Green, M.L.; Lescure, F.-X.; Nicastri, E.; Oda, R.; Yo, K.; Quiros-Roldan, E.; Studemeister, A.; Redinski, J.; Ahmed, S.; Bernett, J.; Chelliah, D.; Chen, D.; Chihara, S.; Cohen, S.H.; Cunningham, J.; D’Arminio Monforte, A.; Ismail, S.; Kato, H.; Lapadula, G.; L’Her, E.; Maeno, T.; Majumder, S.; Massari, M.; Mora-Rillo, M.; Mutoh, Y.; Nguyen, D.; Verweij, E.; Zoufaly, A.; Osinusi, A.O.; DeZure, A.; Zhao, Y.; Zhong, L.; Chokkalingam, A.; Elboudwarej, E.; Telep, L.; Timbs, L.; Henne, I.; Sellers, S.; Cao, H.; Tan, S.K.; Winterbourne, L.; Desai, P.; Mera, R.; Gaggar, A.; Myers, R.P.; Brainard, D.M.; Childs, R.; Flanigan, T. Compassionate Use of Remdesivir for Patients with Severe COVID-19. New Engl. J. Med. 2020, 382, 2327-2336, https://doi.org/10.1056/NEJMoa2007016.

9. Beigel, J.H.; Tomashek, K.M.; Dodd, L.E.; Mehta, A.K.; Zingman, B.S.; Kalil, A.C.; Hohmann, E.; Chu, H.Y.; Luetkemeyer, A.; Kline, S.; Lopez de Castilla, D.; Finberg, R.W.; Dierberg, K.; Tapson, V.; Hsieh, L.; Patterson, T.F.; Paredes, R.; Sweeney, D.A.; Short, W.R.; Touloumi, G.; Lye, D.C.; Ohmagari, N.; Oh, M.-d.; Ruiz-Palacios, G.M.; Benfield, T.; Fätkenheuer, G.; Kortepeter, M.G.; Atmar, R.L.; Creech, C.B.; Lundgren, J.; Babiker, A.G.; Pett, S.; Neaton, J.D.; Burgess, T.H.; Bonnett, T.; Green, M.; Makowski, M.; Osinusi, A.; Nayak, S.; Lane, H.C. Remdesivir for the Treatment of COVID-19-Preliminary Report. New Engl. J. Med., 2020, https://doi.org/10.1056/NEJMoa2007764.

10. Jorgensen, S.C.J.; Kebriaei, R.; Dresser, L.D. Remdesivir: Review of Pharmacology, Pre-Clinical Data and Emerging Clinical Experience for COVID-19. Pharmacology, J. Hum Pharm. Drug. Ther. 2020, 40, https://doi.org/10.1002/phar.2329.

11. Azevedo, T.C.P.D.; Azevedo, P.C.P.D.; Silveira Filho, R.N.; Carvalho, A.R.V.S.D.; Cezarotti Filho, M.L.; Barbosa, F.T.; Sousa-Rodrigues, C.F.D.; Matos-Rocha, T.J.; Ramos, F.W.D.S. Use of remdesivir for patients with Covid-19: a review article. J Revista da Associação Médica Brasileira 2020, 66, 838-841, https://doi.org/10.1590/1806-9282.66.6.838

https://biointerfaceresearch.com/ 
12. Singh, A.K.; Singh, A; Singh, R.; Misra, A. Remdesivir in COVID-19: A Critical Review of Pharmacology, Pre-Clinical and Clinical Studies. Diab. Met. Synd. 2020, 14, 641-648, https://doi.org/10.1016/j.dsx.2020.05.018.

13. Wang, Y.; Zhang, D.; Du, G.; Du, R.; Zhao, J.; Jin, Y.; Fu, S.; Gao, L.; Cheng, Z.; Lu, Q.; Hu, Y.; Luo, G.; Wang, K.; Lu, Y.; Li, H.; Wang, S.; Ruan, S.; Yang, C.; Mei, C.; Wang, Y.; Ding, D.; Wu, F.; Tang, X.; Ye, X.; Ye, Y.; Liu, B.; Yang, J.; Yin, W.; Wang, A.; Fan, G.; Zhou, F.; Liu, Z.; Gu, X.; Xu, J.; Shang, L.; Zhang, Y.; Cao, L.; Guo, T.; Wan, Y.; Qin, H.; Jiang, Y.; Jaki, T.; Hayden, F.G.; Horby, P.W.; Cao, B.; Wang, C. Remdesivir in Adults with Severe COVID-19: A Randomized, Double-Blind, Placebo-Controlled Multicentre Trial. Lancet 2020, 395, 1569-1578, https://doi.org/10.1016/S0140-6736(20)31022-9.

14. Al-Tannak, N.F.; Novotny, L; Alhunayan, A. Remdesvir-Bringing Hope for COVID-19 Treatment. Sci. Pharm. 2020, 88, https://doi.org/10.3390/scipharm88020029.

15. Avataneo, V.; de Nicolò, A.; Cusato, J.; Antonucci, M.; Manca, A.; Palermiti, A.; Waitt, C.; Walimbwa, S.; Lamorde, M.; di Perri, G.; D’Avolio, A. Development and Validation of a UHPLC-MS/MS Method for Quantification of the Prodrug Remdesivir and Its Metabolite GS-441524: A Tool for Clinical Pharmacokinetics of SARS-CoV2/COVID-19 and Ebola Virus Disease. J. Antimicrob. Chemother. 2020, https://doi.org/10.1093/jac/dkaa152.

16. Sheahan, T.P.; Sims, A.C.; Leist, S.R et al., Comparative Therapeutic Efficacy of Remdesivir and Combination Lopinavir, Ritonavir and Interferon Beta Against MERS-CoV. Nature Comm. 2020, 11, https://doi.org/10.1038/s41467-019-13940-6.

17. Gordon, C.J.; Tchesnokov, E.P.; Woolner, E.; Perry, J.K.; Feng, J.Y.; Porter, D.P.; Götte, M. Remdesivir is a direct-acting antiviral that inhibits RNA-dependent RNA polymerase from severe acute respiratory syndrome coronavirus 2 with high potency. The Journal of biological chemistry 2020, 295, 6785-6797, https://doi.org/10.1074/jbc.RA120.013679.

18. Sisay, M. Available Evidence and Ongoing Clinical Trials of Remdesivir: Could It Be a Promising Therapeutic Option for COVID-19? Front. Pharm. 2020, 11, https://doi.org/10.3389/fphar.2020.00791.

19. El-Badawy, F.M.; Mohamed, M.A; El-Desoky, H.S. Fabrication of an Electrochemical Sensor Based on Manganese Oxide Nanoparticles Supported on Reduced Graphene Oxide for Determination of Subnanomolar Level of Antihepatitis C Daclatasvir in the Formulation and Biological Models. Microchem. J. 2020, 157, https://doi.org/10.1016/j.microc.2020.104914.

20. Ranganathan, P.; Mutharani, B; Chen, Sh.-M.; Sireesha, P. Polystyrene: $\beta$-Cyclodextrine Inclusion ComplexSupported $\mathrm{Y}_{2} \mathrm{O}_{3}$-Based Electrochemical Sensor: Effective and Simultaneous Determination of 4Aminoantipyrine and Acyclovir Drugs. J. Phys. Chem. C. 2019, 123, 12211-12222, https://doi.org/10.1021/acs.jpcc.9b00465

21. Annu; Sharma, S.; Jain, R.; Raja, N.A. Review-Pencil Graphite Electrode: An Emerging Sensing Material. J. Electrochem. Soc. 2019, 167, https://doi.org/10.1149/2.0012003JES

22. Rezvani, J. Synthesis of $\mathrm{Ag}_{2} \mathrm{O}_{2}$ Semiconductor Micropowder by Plasma Electrolysis Method and Its Optical Characterization. Iran J. Cer Sci. 2020, 8, 69-79.

23. Lima, E.; Boto, R.; Ferreira, D.; R. Fernandes, J.; Almeida, P.; F. V. Ferreira, L.; Souto, E.B.; Silva, A.M.; V. Reis, L. Quinoline- and Benzoselenazole-Derived Unsymmetrical Squaraine Cyanine Dyes: Design, Synthesis, Photophysicochemical Features and Light-Triggerable Antiproliferative Effects against Breast Cancer Cell Lines. Materials 2020, 13, 2646-2660, https://doi.org/10.3390/ma13112646

24. Gomes, V.S.D.; Gonçalves, H.M.R.; Boto, R.E.F.; Almeida, P.; Reis, L.V. Barbiturate squaraine dyes as fluorescent probes for serum albumins detection. Journal of Photochemistry and Photobiology A: Chemistry 2020, 400, https://doi.org/10.1016/j.jphotochem.2020.112710.

25. Butnarasu, C.; Barbero, N.; Barolo, C.; Visentin, S. Squaraine dyes as fluorescent turn-on sensors for the detection of porcine gastric mucin: A spectroscopic and kinetic study. Journal of Photochemistry and Photobiology B: Biology 2020, 205, https://doi.org/10.1016/j.jphotobiol.2020.111838.

26. Maeda, T.; Liess, A.; Kudzus, A.; Krause, A.-M.; Stolte, M.; Amitani, H.; Yagi, S.; Fujiwara, H.; Würthner, F. Hydrogen bond-rigidified planar squaraine dye and its electronic and organic semiconductor properties. Chemical Communications 2020, https://doi.org/10.1039/D0CC04306K.

27. Das, I.; Goel, N.; Agrawal, N.R.; Gupta, S.K.J.T.J.o.P.C.B. Growth patterns of dendrimers and electric potential oscillations during electropolymerization of pyrrole using mono-and mixed surfactants. J. Phys. Chem. B 2010, 114, 12888-12896, https://doi.org/10.1021/jp105183q .

28. Bazzaoui, M.; Bazzaoui, E.A.; Martins, L.; Martins, J.I. Electropolymerization of pyrrole on zinc-leadsilver alloys electrodes in acidic and neutral organic media. Synthetic Metals 2002, 130, 73-83, https://doi.org/10.1016/S0379-6779(02)00101-7.

29. Das, I.; Goel, N.; Gupta, S.K.; Agrawal, N.R.J.J.O.E.C. Electropolymerization of pyrrole: Dendrimers, nanosized patterns and oscillations in potential in presence of aromatic and aliphatic surfactants. J. Electroanal. Chem. 2012, 670, 1-10.

30. Tkach, V.V.; Storoshchuk, N.M.; Romaniv, L.V.; De Oliveira, S.C.; Luganska, O.V.; Gala, H.B.; Tchikuala, E.F.; Yagodynets, P.I. The theoretical evaluation of the poly (3, 4'dimetylpyrrole) cathodic electrodeposition assisted by manganate ions. Vietnam .J. Chem. 2018, 56, 440-444, https://doi.org/10.1002/vjch.201800027 
31. Tkach, V.; Storoshchuk, N.; de Oliveira, S.; Luganska, O.; Gala, H.; Tchikuala, E.; Palamarek, K.; Nezveshchuk-Kohut, T.; Yagodynets, P. The Theoretical Evaluation of the Poly (3,4-dimethylpyrrole) Cathodic Electrodeposition, Assisted by Manganate Ions, Intercalated into a Conducting Polymer. Appl. J. Env. Eng. Sci. 2018, 4, 328-336.

32. Tkach, V.; Kushnir, M.; Storoshchuk, N.; de Oliveira, S.; Luganska, O.; Parchenko, V.; Bigdan, A.; Yagodynets', P. The Theoretical Description of Cathodic Pyrrole Electrodeposition, Assisted by a Dichromate of a Novel Triazolic Derivative. Rhazes 2018, 2.

33. Tkach, V.; Kushnir, M.; Ivanushko, Y.; de Oliveira, S.; Reis, L.; Yagodynets', P.; Kormosh, Z. The Theoretical Description for Neotame Electrochemical Determination, Assisted by Vanadium Oxyhydroxide Composite with a Squarainic Dye. Appl. J. Env. Eng. Sci., 2020, 6, 109-115.

34. Tkach, V.; Kushnir, M.; Storoshchuk, N.; Ivanushko, Y.; de Oliveira, S.; Yagodynets', P.; Kormosh, Z. The Theoretical Description for the Confection of the Novel Thiourea-Based Active Surface for Cathodic Conducting Polymer Deposition. Appl. J. Env. Eng. Sci. 2020, 6, 143-148.

35. Tkach, V.; Kushnir, M.; Ivanushko, Y.; de Oliveira, S.; Reis, L.; Yagodynets', P.; Kormosh, Z. The Theoretical Description for the Electrochemical Synthesis of Squaraine Dye Doped Conducting Polymer. Appl. J. Env. Eng. Sci. 2020, 6, 51-56. 